\title{
MRI-Guided Transurethral Ultrasound Ablation
}

National Cancer Institute

\section{Source}

National Cancer Institute. MRI-Guided Transurethral Ultrasound Ablation. NCI Thesaurus.

Code C128626.

The use of high-intensity ultrasound, via a transurethral approach and using MRI-

guidance, to destroy tissue. 